\title{
Pengaruh pH Fermentasi dan Putaran Pengadukan pada Fermentasi Molasses terhadap Produksi Bioetanol
}

\author{
Annisa Fitriyah Permata Cika ${ }^{* 1}$, Yuli Uztamila ${ }^{2}$, Sahrul Effendy A ${ }^{3}$, Aida Syarif ${ }^{4}$, Ibnu Hajar ${ }^{5}$ \\ 1,2,3,4,5Program Studi Teknik Energi, Jurusan Teknik Kimia \\ Politeknik Negeri Sriwijaya, Indonesia. \\ Email: ${ }^{1}$ annisafpcika@gmail.com, ${ }^{2}$ yuliuztamila21@gmail.com
}

\begin{abstract}
Abstrak
Bioetanol merupakan bahan kimia yang dapat digunakan sebagai pelarut, antiseptik dan juga bahan bakar alternatif. Salah satu bahan baku yang dapat dimanfaatkan dalam pembuatan bioetanol adalah molase atau tetes tebu yang merupakan sisa pembuatan gula tebu namun masih mengandung glukosa yang tinggi. Komposisi yang penting dalam molase adalah TSAI (Total Sugar as Inverti) yaitu gabungan dari sukrosa dan gula reduksi. Molases memiliki kadar TSAI antara 50 - 65\%. Konversi molase menjadi bioetanol dilakukan dengan cara fermentasi didalam fermentor. Fermentor berpengaduk merupakan salah satu tipe fermentor yang banyak digunakan. Pengadukan berfungsi untuk meratakan kontak sel dan substrat, menjaga agar mikroorganisme tidak mengendap dibawah bagian bioreaktor. Kualitas dan kuantitas hasil fermentasi dapat dipengaruhi oleh derajat keasaman, $\mathrm{pH}$ yang terlalu rendah (asam) atau terlalu tinggi (basa) dapat memicu tingkat kematian sel mikroba. Selain itu, kecepatan pengadukan juga berpengaruh terhadap kontak substrat dalam fermentor untuk mengonversi molase. Artikel ini membahas tentang kengaruh $\mathrm{pH}$ fermentasi $(4,4,5,5,5,5$, dan 6$)$ dan kecepatan pengadukan $(15,35,55,75,95 \mathrm{rpm})$ terhadap kualitas dan kuantitas produksi bioetanol menggunakan fermentor berpangaduk. Dari penelitian ini didapatkan Ph optimal termentasi mulai dari pH fermentasi 5,5 sampai dengan 6 dan kecepatan pengadukan optimum pada penelitian ini adalah $95 \mathrm{rpm}$.
\end{abstract}

Kata kunci: bioetanol, fermentasi, fermentor berpengaduk, kecepatan pengadukan, ph fermentasi.

\section{Effect of Fermentation pH and Stirring Rate of Molasses Fermentation on Bioethanol Production}

\begin{abstract}
Bioethanol is a chemical that can be used as a solvent, antiseptic and alternative fuels. One of the raw materials that can be used in the production of bioethanol is molasses which is the residue from the manufacture of cane sugar but still contains high glucose. An important composition in molasses is TSAI (Total Sugar as Inverti) which is a combination of sucrose and reducing sugar. Molasses has TSAI levels between $50-65 \%$. The conversion of molasses into bioethanol is carried out by fermentation in a fermenter. Stirred fermenter is one type of fermenter that is widely used. Stirring used to even out the cell and substrate contacts, to keep microorganisms from settling below the bioreactor. Quality and quantity of the fermentation products can be affected by the degree of acidity, $\mathrm{pH}$ that is too low (acidic) or too high (alkaline) can trigger the level of microbial cell death. Stirring rate is also can affect the molase coversion. This paper will discuss about the effect of different fermentation $\mathrm{pH}(4,4,5,5,5,5$, dan 6) and stirring rate $(15,35,55,75,95 \mathrm{rpm})$ to quality and quantity of the bioethanol product in a stirred tank fermenter. Optimal fermentation Ph is about 5,5 to 6 and optimal stirring rate is 95 rpm.
\end{abstract}

Keywords: bioethanol, fermentation, fermentation ph, stirred tank fermentor, stirring rate.

\section{PENDAHULUAN}

Bioetanol merupakan bahan kimia yang dapat digunakan sebagai pelarut, antiseptik dan juga bahan bakar alternatif [1]. Bahan baku produksi etanol terdiri dari tiga jenis yaitu bahan baku yang mengandung sukrosa, pati dan lignoselulosa. Bahan baku yang mengandung sukrosa yang merupakan bahan baku generasi pertama banyak digunakan karena proses pengkonversiannya menjadi bioetanol lebih sederhana dan tidak perlu melalui hidrolisis seperti yang dilakukan pada bahan baku yang mengandung pati dan lignoselulosa. 
Salah satu bahan baku sukrosa yang dapat dimanfaatkan adalah molase atau tetes tebu yang merupakan sisa pembuatan gula tebu namun masih mengandung glukosa dan nutrisi tinggi. Molase adalah hasil samping pada pembuatan gula tebu (Saccharum officinarum). Bahan baku molase memiliki harga yang murah dan mudah didapatkan. Molase mengandung sebagian besar gula, asam amino dan mineral dengan pH sekitar 4,5-5,6. Sukrosa yang terdapat dalam tetes tebu bervariasi antara $25-40 \%$, dan kadar gula reduksinya $12-35 \%$. Komposisi yang penting dalam molases adalah TSAI (Total Sugar as Inverti) yaitu gabungan dari sukrosa dan gula reduksi. Molases memiliki kadar TSAI antara $50-65 \%$. Angka TSAI ini sangat penting bagi industri fermentasi karena semakin besar TSAI akan semakin menguntungkan [2]. Untuk pembuatan etanol, molase harus mendapat perlakuan pretreatment karena molase bersifat kental, kadar gula dan pH-nya masih terlalu tinggi [3].

Selama fermentasi batch, akan terbentuk inhibitor yang dapat disebabkan oleh mineral atau konsentrasi substrat molase. Kandungan mineral dalam bentuk $\mathrm{Ca}, \mathrm{K}$, dan $\mathrm{Mg}$ dan konsentrasi gula yang terkandung dalam molase tebu harus dipertimbangkan dalam proses fermentasi. Strategi yang dapat digunakan untuk mengurangi kandungan mineral terutama kalsium adalah decalcification menggunakan $\mathrm{H}_{2} \mathrm{SO}_{4}$ [4].

Perlakuan $\mathrm{pH}$ medium fermentasi akan memberikan pengaruh terhadap produksi bioetanol. $\mathrm{pH}$ merupakan kondisi asam-basa medium suatu mikroorganisme yang dapat mempengaruhi pertumbuhan (aktivitas pembelahan sel) dari mikroorganisme tertentu. $\mathrm{pH}$ merupakan kondisi asam basa medium fermentasi yang berhubungan dengan aktivitas pertumbuhan mikroorganisme [5]. $\mathrm{pH}$ yang terlalu rendah (asam) atau terlalu tinggi (basa) dapat memicu tingkat kematian sel mikroba. Tingkat kematian mikroorganisme yang tinggi akan berpengaruh terhadap kecepatan fermentasi, karena jumlah mikroba akan berkurang dalam mengurangi glukosa menjadi etanol.

Konversi molase menjadi bioetanol dilakukan dengan cara fermentasi didalam fermentor. Mikroorganisme yang umumnya digunakan dalam proses produksi bioetanol adalah Saccharomyces cerevisiae. S. cerevisiae memiliki beberapa kelebihan diantaranya mudah beradaptasi dengan lingkungan, lebih tahan terhadap kadar alkohol tinggi, dan lebih mudah didapat [6]. Fermentor berfungsi sebagai suatu tempat atau wadah yang menyediakan lingkungan yang tepat dan dapat dikontrol untuk pertumbuhan dan aktivitas mikrobia atau kultur campuran tertentu untuk menghasilkan produk yang diinginkan [2]. Fermentor berpengaduk merupakan salah satu tipe fermentor yang banyak digunakan. Pengadukan berfungsi untuk meratakan kontak sel dan substrat, menjaga agar mikroorganisme tidak mengendap dibawah dan meratakan temperatur di seluruh bagian bioreaktor [7]. Kecepatan pengaduk yang tepat diharapkan dapat menunjang fungsi pengadukan sehingga dapat meningkatkan hasil fermentasi. Selain itu pengadukan juga berfungsi sebagai pemecah sel berkoloni sehingga sel - sel mikroorganisme tidak menyatu membentuk gumpalan (flok) yang akan mengganggu perkembangbiakan sel yang tidak mendapatkan nutrisi yang cukup dari substrat. Pengadukan yang terlalu cepat dapat mengakibatkan kontak antara enzim yang dihasilkan dari saccharomyces cerevisiae dengan substrat glukosa menjadi berkurang dan tidak maksimal yang mengakibatkan glukosa yang terkonversi menjadi bioetanol menjadi lebih sedikit [8]. Tujuan dari penelitian ini adalah untuk pendapatkan produk bioetanol yang mempunyai karakteristik seperti bioetanol ber standar nasional Indonesia.

\section{METODE PENELITIAN}

\subsection{Alat dan Bahan}

\subsubsection{Alat}

Alat yang digunakan dalam penelitian ini diantaranya, set alat fermentor, neraca analitik, hot plate, gelas kimia $250 \mathrm{ml}$, pipet ukur $25 \mathrm{ml}$, bola karet, termometer $360^{\circ} \mathrm{C}$, set alat distilasi, piknometer $5 \mathrm{ml}$, refraktometer abbe, dan bom calorimeter.

\subsubsection{Bahan}

Bahan yang digunakan dalam penelitian ini diantaranya, tetes tebu (molase), Baker Yeast (Saccharomyces Cerevisae) merk 'fermipan', Urea, NPK, $\mathrm{H}_{2} \mathrm{SO}_{4}$, dan $\mathrm{NaOH}$.

\subsection{Prosedur Penelitian}

Urutan Langkah kerja yang dilakukan dalam penelitian ini adalah sebagai berikut:

Pretreatment: Tetes tebu sebanyak $1 \mathrm{~kg}$ diencerkan dengan menggunakan air dengan perbandingan 1:1.

Dekalkifikasi: Menambahkan larutan $\mathrm{H}_{2} \mathrm{SO}_{4}$ pekat (96\%) ke sampel yang telah diencerkan sampai $\mathrm{pH}$ menurun menjadi 3,9. Setelah ditambahkan $\mathrm{H}_{2} \mathrm{SO}_{4}$ pekat, bahan baku dipanaskan hingga suhu $100^{\circ} \mathrm{C}$ selama 30 menit, lalu diendapkan selama 24 jam. Larutan dipisahkan dari endapan.

Fermentasi: Larutan bahan baku diencerkan kembali sampai kadar gula dalam tetes tebu tersebut sebesar $20 \%$, lalu memasukkannya ke dalam fermentor berpengaduk. Menambahkan Baker Yeast (Saccharomyces 
Cereviseae) sebanyak 13,125 gr, Urea sebanyak 7,8125 gr dan NPK sebanyak 6,5625 gr. pH fermentasi diatur (4, 4,5, 5, 5,5, dan 6) dengan menggunakan pompa dosing dengan menambahkan $\mathrm{H}_{2} \mathrm{SO}_{4}$, dan $\mathrm{NaOH}$ masingmasing 1M. Fermentasi dilakukan pada suhu ruang seama 72 jam dan pada laju pengadukan kecepatan pengadukan diatur pada motor pengaduk pada kecepatan 15, 35, 55, 75, $95 \mathrm{rpm}$.

Distilasi: Distilasi dilakukan pada setengan volume hasil fermentasi dengan menggunakan alat distilasi sederhana pada suhu $78^{\circ} \mathrm{C}$ selama 1 jam.

Analisa Sifat Fisik Hasil Percobaan: Analisa yang dilakukan adalah Analisa indeks bias menggunakan refraktometer abbe, analisa densitas dengan menggunakan piknometer $5 \mathrm{ml}$.

\section{HASIL DAN PEMBAHASAN}

Data hasil dan rendemen bioetanol dari distilasi setengah volume fermentasi disajikan pada Gambar 1.

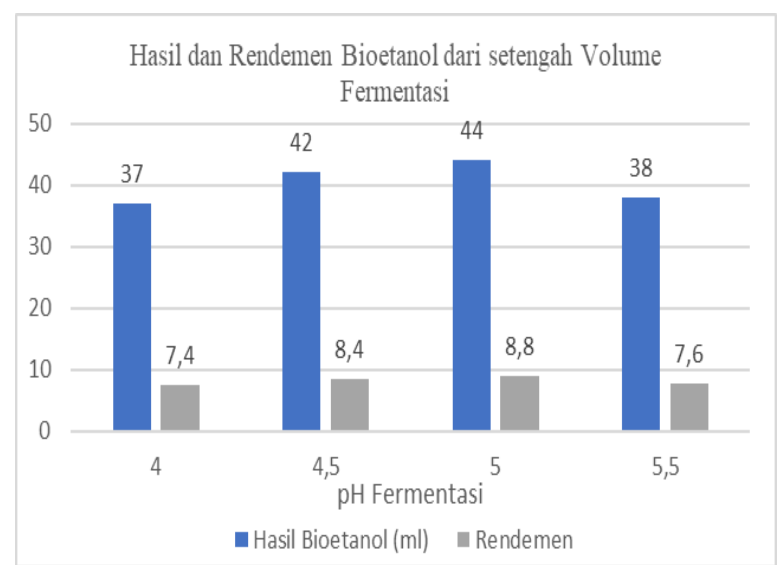

Gambar 1. Hasil dan Rendemen Bioetanol dari Setengah Volume Fermentasi

Terlihat pada Gambar.1 grafik di atas rendemen bioetanol terbesar didapatkan pada pH fermentasi 5 sedangkan rendemen bioetanol terkecil didapatkan pada $\mathrm{pH}$ fermentasi 5,5. Perbedaan rendemen bioetanol ini disebabkan oleh efek keasaman terhadap pertumbuhan mikroba pada proses fermentasi. Jika $\mathrm{pH}$ fermentasi tidak sesuai dengan lingkungan ragi, maka pertumbuhan mikroba terhalang. Dalam penelitian yang dilakukan oleh Antonio Rudolph juga dijelaskan bahwa fermentasi yang dilakukan dengan menggunakan ragi yang sama dengan ragi yang digunakan pada penelitian ini (saccharomyces cerevisiae), menghasilkan yield bioetanol yang paling optimal pada $\mathrm{pH}$ fermentasi 5.

Bioetanol yang dihasilkan diuji sifat fisiknya untuk mengetahui kualitas bioetanol. Analisa yang dilakukan yaitu indeks bias menggunakan refraktometer abbe, densitas menggunakan piknometer 5 ml dan nilai kalor menggunakan bom kalorimeter. Hasil analisa sifat fisik bioetanol diuraikan pada Gambar 2, Gambar 3 dan Gambar 4 grafik berikut.

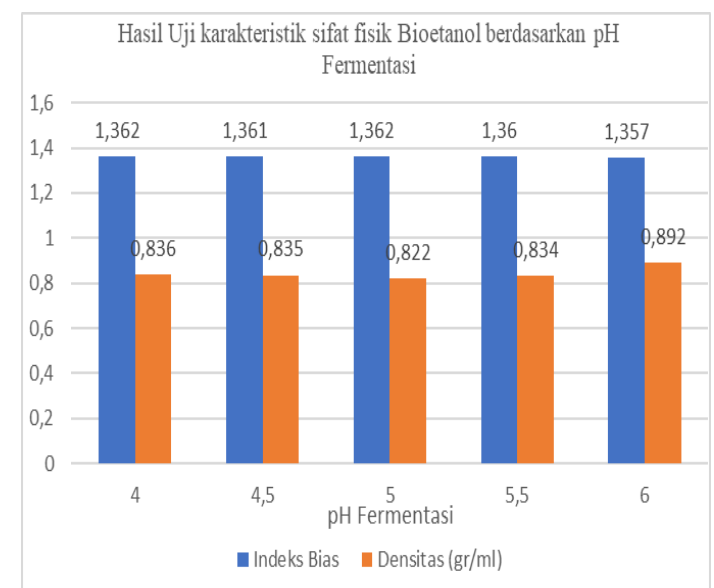

Gambar 2. Hasil Uji karakteristik sifat fisik bioethanol berdasarkan pH Fermentasi 


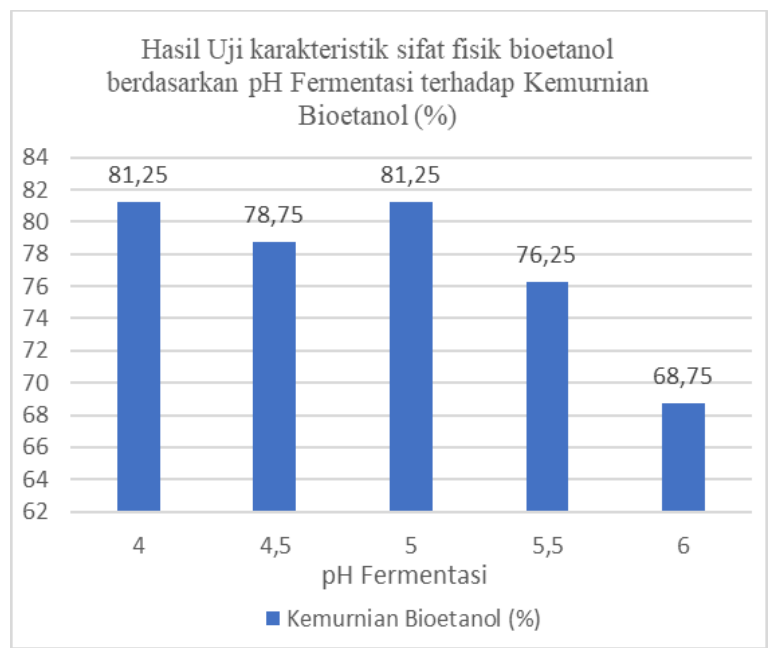

Gambar 3. Hasil Uji karakteristik sifat fisik bioethanol berdasarkan $\mathrm{pH}$ Fermentasi terhadap Kemurnian Bioetanol (\%)

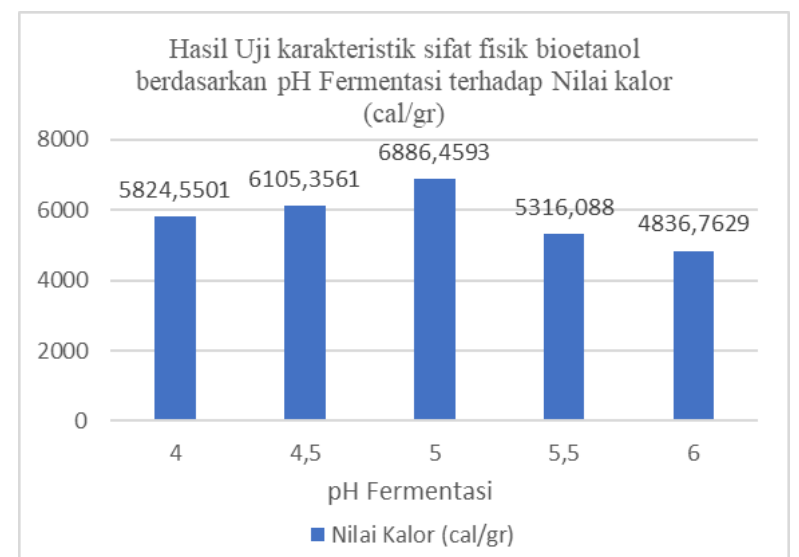

Gambar 4. Hasil Uji karakteristik sifat fisik bioetanol berdasarkan pH Fermentasi terhadap Nilai kalor $(\mathrm{cal} / \mathrm{gr})$

Persen rendemen bioetanol yang dihasilkan juga berhubungan dengan kemurnian bioetanol yang dihasilkan. Kemurnian bioetanol dihitung dengan menggunakan persamaan yang didapat dari kurva baku etanolair kemurnian bioetanol tertinggi didapatkan pada $\mathrm{pH}$ fermentasi 5. Perbedaan kemurnian bioetanol yang dihasilkan berhubungan dengan kemampuan tumbuh ragi. Pada $\mathrm{pH}$ 5, ragi memasuki fase pertumbuhan yang lebih cepat. $\mathrm{pH}$ asam membantu degradasi sukrosa menjadi fermentable sugars oleh ensim invertase. Pada $\mathrm{pH}$ 6, kemurnian bioetanol yang dihasilkan adalah yang paling rendah dikarenakan saccharomyces cerevisiae memasuki fase stasioner sehingga tidak dapat bekerja dengan optimal. Kurangnya kerja ragi ini dikarenakan kadar gula yang merupakan sumber karbon untuk ragi semakin menurun dan dapat menyebabkan ragi mati. Matinya ragi ditandai dengan terbentuknya produk samping fermentasi yang merupakan asam asetat.

Pengadukan berfungsi untuk menghomogenkan larutan dan memperluas bidang permukaan kontak substrat, enzim dan yeast sehingga mempengaruhi bioetanol yang dihasilkan[8]. Fungsi pengadukan selain penyeragaman kontak di dalam media cair adalah sebagai pemecah sel berkloni sehingga sel-sel mikroorganisme tidak menyatu membentuk gumpalan-gumpalan (flok). Sebab bila sel yang terdapat di dalam media cair membentuk flok maka pengembangbiakan sel akan terganggu akibat sel tersebut tidak mendapatkan makanan yang cukup dari substrat [9]. Bioetanol yang dihasilkan juga diuji sifat fisiknya untuk mengetahui kualitas bioetanol. Analisa yang dilakukan yaitu indeks bias menggunakan refraktometer abbe, densitas menggunakan piknometer $5 \mathrm{ml}$, jumlah yeald bioetanol $(\mathrm{gr} / \mathrm{ml})$ dan nilai kalor menggunakan bom kalorimeter. Hasil analisa sifat fisik bioetanol diuraikan pada Gambar 5, Gambar 6 dan Gambar 7 grafik berikut.

Kecepatan pengadukan optimum bagi sel Saccharomyces cerevisiae berkontak terhadap substrat dalam bioreaktor fermentor untuk mengkonversi molase menjadi bioetanol pada penelitian ini adalah $95 \mathrm{rpm}$.

Badan Standarisasi Nasional menyatakan bahwa standar indeks bias etanol sebagai bahan bakar sebesar 1,3633. Hasil bioetanol yang paling mendekati standar tersebut merupakan sampel dengan $\mathrm{pH}$ fermentasi 5 
dengan indeks bias 1,362. Kemudian hasil bioetanol yang paling mendekati standar tersebut merupakan sampel dengan laju pengadukan 95 rpm indeks bias 1,3600 Indeks bias ini juga berhubungan dengan kadar bioetanol, semakin mendekati standar, semakin besar juga kadar etanol.

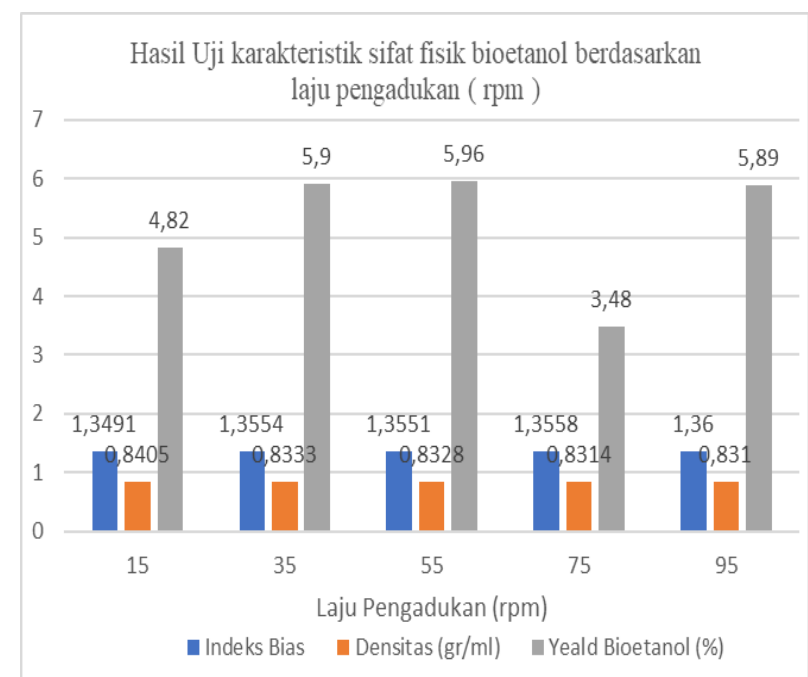

Gambar 5. Hasil Uji karakteristik sifat fisik bioetanol berdasarkan laju pengadukan (rpm)

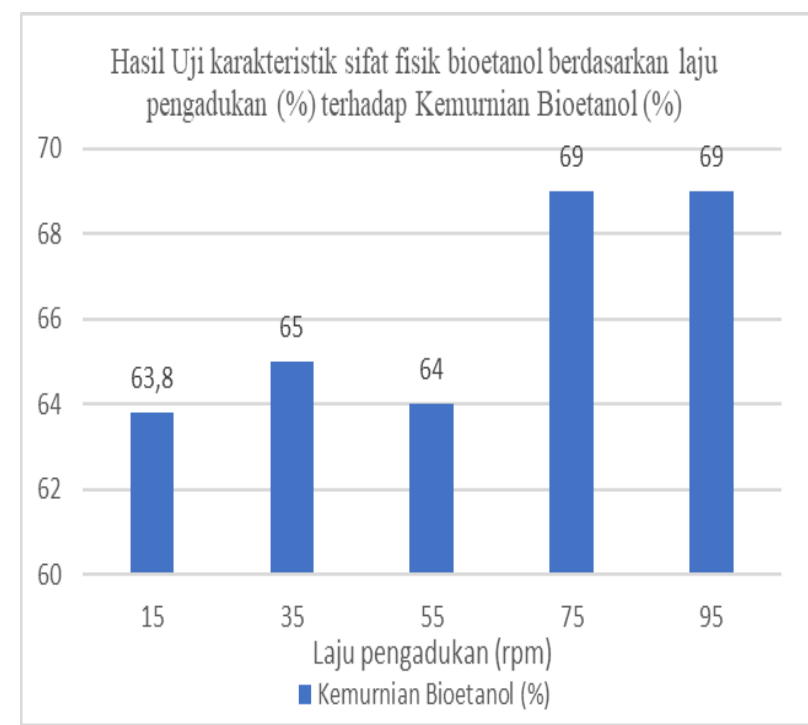

Gambar 6. Hasil Uji karakteristik sifat fisik bioetanol berdasarkan laju pengadukan (rpm) terhadap Kemurnian Bioetanol (\%)

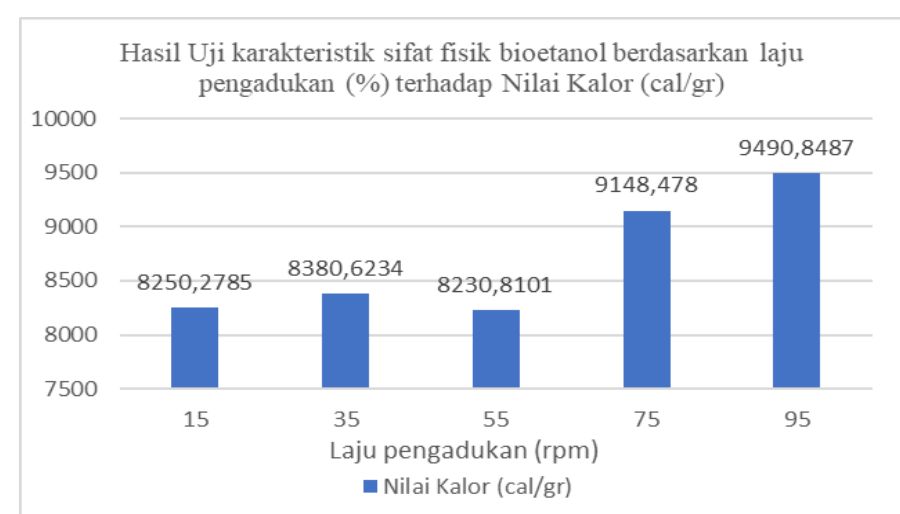

Gambar 7. Hasil Uji karakteristik sifat fisik bioetanol berdasarkan laju pengadukan (\%) terhadap Nilai kalor (cal/gr) 
Badan Standarisasi Nasional menyatakan bahwa standar indeks bias etanol sebagai bahan bakar sebesar 1,3633. Hasil bioetanol yang paling mendekati standar tersebut merupakan sampel dengan $\mathrm{pH}$ fermentasi 5 dengan indeks bias 1,362. Kemudian hasil bioetanol yang paling mendekati standar tersebut merupakan sampel dengan laju pengadukan 95 rpm indeks bias 1,3600 Indeks bias ini juga berhubungan dengan kadar bioetanol, semakin mendekati standar, semakin besar juga kadar etanol.

Densitas bahan bakar diduga akan sangat berpengaruh terhadap laju konsumsi bahan bakar. Semakin besar densitasnya diprediksi akan semakin meningkat konsumsi bahan bakar atau semakin boros. Densitas yang besar akan menghasilkan nilai kalor yang kecil sehingga menyebabkan kualitasnya rendah. Densitas berpengaruh kepada kualitas bioetanol semakin mendekati standar densitas etanol, semakin tinggi kualitas bioetanol yang dihasilkan, dalam hal ini densitas bioetanol yang paling mendekati standar dari Badan Standarisasi Nasional $(0,79 \mathrm{gr} / \mathrm{ml})$ adalah densitas bioetanol yang dihasilkan pada $\mathrm{pH}$ fermentasi 5 . Kemudian densitas bioetanol yang paling mendekati standar dari Badan Standarisasi Nasional $(0,79 \mathrm{gr} / \mathrm{ml})$ adalah densitas bioetanol yang dihasilkan pada laju pengadukan $95 \mathrm{rpm}$ sebesar $(0,8310 \mathrm{gr} / \mathrm{ml})$ Bioetanol yang dihasilkan pada $\mathrm{pH}$ fermentasi 6 memiliki densitas yang tinggi dan jauh dari standar dikarenakan masih terdapat banyak kandungan air yang bisa juga ditunjukkan oleh kadar etanolnya yang lebih rendah dari sampel lain.

Nilai kalor menunjukkan kemampuan bakar bioetanol, semakin besar nilai kalor semakin mudah terbakar bioetanol. Semakin mudah terbakarnya bahan bakar, semakin bagus pula kualitas bahan bakar tersebut. Semakin tinggi nilai kalor suatu bahan bakar maka energi yang dihasilkan pun akan semakin efisien, karena menghasilkan panas yang lebih besar dengan massa yang sedikit [10]. Berdasarkan tes nyala, semua sampel dapat menyala dan memiliki api yang biru. Dari analisis nilai kalor dapat ditunjukkan bahwa bioetanol yang dihasilkan dari fermentasi pada pH 5 semakin mudah terbakar karena memiliki nilai kalor yang paling tinggi sebesar 6886,4593 cal/gr. Berbanding terbalik dengan bioetanol yang dihasilkan pada fermentasi dengan pH 6 yang memiliki nilai kalor paling kecil dari sampel lain yaitu sebesar 4836,7629 cal/gr. Kemudian juga dari analisis nilai kalor dapat ditunjukkan bahwa bioetanol yang dihasilkan dari fermentasi pada laju pengadukan 95rpm semakin mudah terbakar karena memiliki nilai kalor yang paling tinggi sebesar 9490,8487 cal/gr.

\section{KESIMPULAN}

Berdasarkan analisis kuantitas dan kualitas bioetanol, bioetanol yang memiliki kuantitas dan kualitas paling baik adalah bioetanol yang dihasilkan pada fermentasi dengan $\mathrm{pH}$ 5. Terjadi kenaikan kualitas dan kuantitas bioetanol dari $\mathrm{pH}$ fermentasi 4 sampai 5 yang merupakan $\mathrm{pH}$ optimal lalu terjadi penurunan disebabkan karena adanya penurunan konsenterasi gula yang menjadi sumber karbon pada fermentasi mulai dari $\mathrm{pH}$ fermentasi 5,5 sampai dengan 6. Kecepatan pengadukan optimum bagi sel Saccharomyces cerevisiae berkontak terhadap substrat dalam bioreaktor fermentor untuk mengkonversi molase menjadi bioetanol pada penelitian ini adalah 95 rpm.

\section{DAFTAR PUSTAKA}

[1] Y. Hartantio, R. S. Hartati, and I. N. S. Kumara, "Analisa Penggunaan Bahan Bakar Bioetanol Dari Limbah Kertas Sebagai Bahan Bakar Genset," Maj. Ilm. Teknol. Elektro, vol. 17, no. 3, p. 433, 2018, doi: 10.24843/mite.2018.v17i03.p19.

[2] A. Rochani and S. Yuniningsih, “Terhadap Kadar Etanol Pada Proses Fermentasi,” vol. 1, no. 1, pp. 4348, 2016.

[3] A. Anggraini, S. Yuningsih, and M. M. Sota, "Pengaruh pH Terhadap Kualitas Produk Etanol,” J. Reka Buana, vol. 2, no. 2, pp. 99-105, 2017.

[4] R. Raharja, U. Murdiyatmo, A. Sutrisno, and A. K. Wardani, "Bioethanol production from sugarcane molasses by instant dry yeast," IOP Conf. Ser. Earth Environ. Sci., vol. 230, no. 1, 2019, doi: 10.1088/1755-1315/230/1/012076.

[5] M. Taslim, M. Mailoa, and M. Rijal, "PENGARUH pH, DAN LAMA FERMENTASI TERHADAP PRODUKSI ETHANOL DARI Sargassum crassifolium,” Biosel Biol. Sci. Educ., vol. 6, no. 1, p. 13, 2017, doi: 10.33477/bs.v6i1.129.

[6] N. Azizah, A. Al-bAARI, and S. Mulyani, "Pengaruh Lama Fermentasi Terhadap Kadar Alkohol, pH, dan Produksi Gas pada Proses Fermentasi Bioetanol dari Whey dengan Substitusi Kulit Nanas," J. Apl. Teknol. Pangan, vol. 1, no. 2, pp. 72-77, 2012.

[7] R. Kurniawan, S. Juhanda, R. Syamsudin, and M. A. Lukman, "Pengaruh Jenis dan Kecepatan Pengaduk pada Fermentasi Etanol Secara Sinambung dalam Bioreaktor Tangki Berpengaduk Sel Tertambat," STU 10 Novemb. 2011, no. November, pp. 1-14, 2012. 
[8] F. Wibowo, Chairul., and I. S, "Pengaruh Kecepatan Pengaduk dan Waktu Fermentasi Terhadap Konsentrasi Bioetanol Pada Fermentasi Nira Nipah Kental Menggunakan Saccharomyces Cerevisiae," Jom Fteknik, vol. 2, pp. 1-6, 2015.

[9] I. Oktaviani, A. Ahmad, and Chairul, "Pengaruh laju pengadukan terhadap biokonversi reject nanas menjadi bioetanol,” JOM FTEKNIK, vol. 2, no. 1, p.1- 8, 2015.

[10] R. Irzon, "Perbandingan Calorific Value Beragam Bahan Bakar Minyak yang Dipasarkan di Indonesia Menggunakan Bomb Calorimeter," Geo-Resources, vol. 22, no. 4, p. 438, 2012. 